\title{
Role of Moringa Stenopetala Based Agroforestry Practice on Rural Household Economy in Offa Woreda, Southern Ethiopia
}

\author{
Tagay Taye ${ }^{1}$, Yemiru Tesfaye ${ }^{2}$ \\ ${ }^{1}$ Department of Natural Resources Management, Wolkite University, Wolkite, Ethiopia \\ ${ }^{2}$ Wondo Genet College of Forestry and Natural Resources, Hawassa University, Shashmene, Ethiopia \\ Email address: \\ taytag7@gmail.com (T. Taye)
}

\section{To cite this article:}

Tagay Taye, Yemiru Tesfaye. Role of Moringa Stenopetala Based Agroforestry Practice on Rural Household Economy in Offa Woreda, Southern Ethiopia. International Journal of Economy, Energy and Environment. Vol. 6, No. 2, 2021, pp. 29-34. doi: $10.11648 /$ j.ijeee.20210602.12

Received: February 13, 2021; Accepted: April 9, 2021; Published: April 30, 2021

\begin{abstract}
M.stenopetala (Haleko) gained interest lately in Ethiopia due to its plentiful roles. This study aimed at evaluating the planting practice and current role of M.stenopetala based agroforestry in households' economy. In order to attain these objectives three Kebeles were purposively selected. The study made use of data collected from 96 respondents across wealth categories. Then selected households' survey was done through using semi-structured interviews and questionnaires. Data analysed using Excel spread sheet where for economic profitability cost benefit analysis was generated and Net Present Value (NPV) and Benefit-Cost Ratio (BCR) were calculated. Statistical Package for Social Sciences(SPSS) was used for descriptive statistics, chi-square and one way ANOVA. Results revealed that majority of respondents' (66.7) prefer planting M.stenopetala at homegarden agroforestry arrangement because, they perceived as, it enhances the yield of undergrowth root crops. The cost production of M.stenopetala planting is a profitable business with highest positive NPV and B/C which is $181678.22 \mathrm{ETB}$ (US $\$ 6055.94$ ) and 29.98 respectively with a discount rate of 6\% through CBA aggregated over 10 years. This indicates the returns from M.stenopetala planting would be high and economically profitable in the study area. According to One-way ANOVA, annual income gained from M.stenopetala was highest for poor households than medium and rich $(\mathrm{p}<0.05)$. Therefore, it is a useful multipurpose tree in the study area whose promotion should be encouraged in order to realize its full benefits in rural livelihoods since; it associated with more benefits than costs. Therefore, it could be decided that there is a great scope to improve the existing M.stenopetala with suitable approaches for maximizing income of farmers.
\end{abstract}

Keywords: Agroforestery, Cash Income, Cost Benefit Analysis, Moringa, Wealthy Categories

\section{Introduction}

Ethiopia is an agricultural country where large majority of people are engaged in cultivation of food crops and rearing of livestock. Crops are produced for subsistence [1].

Moringa stenopetala is among the most useful multipurpose trees planted and managed by rural people in the dry and sub-humid areas of Ethiopia [2]. Moringa species is one of the world's most useful plants; it is a fast-growing, much more drought-tolerant and multi-purpose tree that it has been described as a 'miracle tree' $[3,4,1,5]$.

M.stenopetala was domesticated in the east African lowlands and is indigenous to southern Ethiopia.
M.stenopetala is often called "cabbage tree" and is an important indigenous vegetable in south western Ethiopia where it is cultivated as a food crop [6]. In Ethiopia it is a native tree in arid, semi-arid and semi-humid areas in the altitudinal ranged 1000 to 1800 m.a.s.l but it also grows from 390 to about 2200 m.a.s.1 in the Southern Rift Valley of Ethiopia [7]. The southern parts of Ethiopia and Northern Kenya are believed to be the origin and place of endemism and diversity to the species [8-10]. The Gofa, Konso, Burji, Dherashe, Debub Omo and Gamo communities consume its leaves as a vegetable, especially during the dry season $[6,11$, 12]. In marginal dry parts of Ethiopia M.stenopetala tree is found intercropped with agricultural crops by the Konso 
people and as on farm tree (homegarden) that supports nearly high population density in South Ethiopia. Moringa trees are multi-purpose trees of economic importance with several industrial and feeding values. It has a wide range of adaptation from arid to humid climates and can be grown in a various land use patterns. It is cultivated both for social food and used as animal feed in Southern Ethiopia and has been recently dispersed to other regions of Ethiopia under its original locations.

M.stenopetala does not have any exact soil requirements, but it prefers a well-drained sandy loam or loamy soils, and also it tolerates a wide range of soil $\mathrm{pH}$ (5-9) from slightly acidic to slightly alkaline. In addition, it tolerates a clay soil excepting it does not grow on wet waterlogged or swampy soils and it does not tolerate prolonged flooding; [13-15].

However, this information and systematic feedback regarding M.stenopetala role on households' economy, its planting cost-benefit and farmers' perception on its environmental impact on agricultural crop is relatively unidentified in the context of Offa Woreda. Consequently, the costs and benefits of planting M.stenopetala tree, evaluating current planting practices, its role in households' economy and farmers' perception of its impacts on environment were the main focus of exploration in the study area. Therefore, this study, which focuses on identifying the major agroforestry practices that use M.stenopetala tree and determining the costs incurred and benefits obtained by rural households from planting M.stenopetala in Offa woreda Southern Ethiopia

\section{Research Methodology}

\subsection{General Description}

This study was undertaken in Offa Woreda Wolaita zone which is located in the Southern Nation, Nationalities, and Peoples Region of Ethiopia (SNNPR). It is located at $37^{\circ} 29^{\prime}$ 59.99" $\mathrm{E}$ and $6^{\circ} 44^{\prime} 59.99^{\prime \prime} \mathrm{N}$ having altitude ranging of 1200-2600 masl which is located below figure 1 . The amount of rain fall and range of temperature were $800-1400 \mathrm{~mm}$ and 14-340C respectively [16].

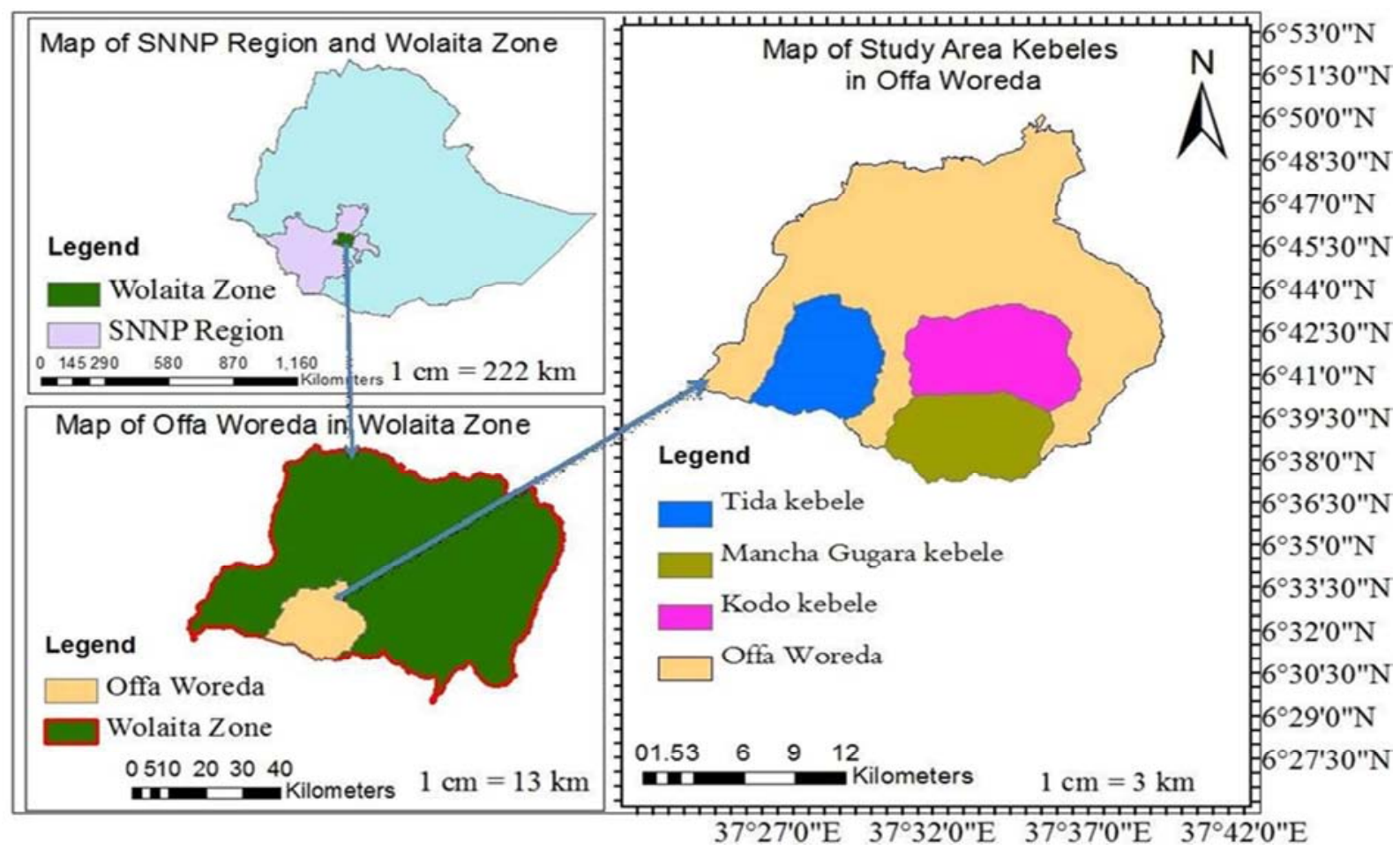

Figure 1. Map of the study area.

\subsection{Research Methods}

\section{Study Site and Household Selection}

Multi-stage sampling techniques which were combinations of purposive, random and stratified sampling methods were applied to select the sample Kebeles and households. The study site was selected purposively based on the presence of M.stenopetala tree plant in farmland practice. Therefore, out of 21 kebeles in Offa Woreda, three representative kebele (Tida, Kodo and Mancha) were purposively selected due to the availability and distribution of M.stenopetala tree based agroforestry practices more than the others in the Woreda. The determination of sample size is fixed by means of Slovin's sampling formula with 90 percent confidence level;

$$
n=\frac{N}{1+N(e)^{2}}
$$

$n=$ sample size for the research use

$N=$ total number of HHs in three M.stenopetala practicing kebele

$e=$ margin of errors at $10 \%$ 
Where, 95\% degree of confidence is selected in the study. Based on this, a total 96 sample households were carried selected proportionally across three wealth categories within the three kebele. Then data collection was done through interview and observation survey of households sampling from M.stenopetala tree growers and focus group discussion with experts of office of WoARD administration office and local administrators.

Methods of data Analysis

The statistical analysis were conducted using statistical software (SPSS version 20), and $X^{2}$ test was also run for any association between the wealth categories related with why primarily they plant this tree. One-way ANOVA was used to test whether there is a significant difference among different household categories.

Financial analysis

Cost-Benefit Analysis (CBA) was applied to estimate only the tangible costs and benefits accrued from M.stenopetala tree planting practices.

Table 1. Equations of economic performance indicators with critical min values.

\begin{tabular}{lll}
\hline Financial indicator & Computation & critical min value \\
\hline Net present value (NPV) & $N P V=\sum_{t=1}^{n} \frac{B t}{(1+r)^{t}}-\sum_{i=0}^{t} \frac{C t}{(1+r)^{t}}$ & $\mathrm{NPV}>0$ \\
Benefit cost ratio (BCR) & $B C R=\sum_{t=1}^{n} \frac{B t}{(1+r)^{t}} / \sum_{i=0}^{t} \frac{C t}{(1+r)^{t}}$ & $\mathrm{BCR}>1$ \\
\hline
\end{tabular}

Where $B_{t}$ denotes benefits in $t, C_{t}$ denotes the costs incurred in $\mathrm{t}$ for $\mathrm{t}=0,1,2 \ldots, 10, \mathrm{n}=$ length of time period, $\mathrm{r}=$ discount rate and $\mathrm{t}=$ number of years, $(1+\mathrm{r}){ }^{\mathrm{t}=}$ discount factor.

Assumption which were under taken during financial analysis;

i) The tax amount is constant over the time

ii) The opportunity cost of the labour used in the cost of family labour cost was 70 ETB /day (local daily labour payment confirmed by FGD)

iii) IR is $6 \%$ based on the current minimum saving interest rate of NBE [17].

\section{Results and Discussion}

\subsection{Demographic and Socio Economic Characteristics of Households}

Among the total sampled respondents, 92\% were male headed households and $8 \%$ were female headed households. There were no significant difference $(p=0.094)$ across wealth categories in terms of age class. The majority of the households $(91.5 \%)$ age ranged from 26 to 64 and some proportion of the households (8.5\%) households' above 65 years, displaying that availability of more productive working. The result shows that almost all respondents are in the productive age category, whereas less than $8.5 \%$ of the respondents belong to age category beyond 65 years. Concerning the education level, $16.7 \%$ were not joined proper education, $62.8 \%$ were attended primary 1 st cycle (grade $1-4$ ), and $18.4 \%$ primary 2 nd cycle (grade 5-8) and the rest $2.1 \%$ were high school (grade 9-12).

\subsection{Major Types of Agroforestry Practices That Use M.stenopetala Tree}

According to farm experience, about $100 \%$ of sampled households had more than five years of experience of growing M.stenopetala. These planting arrangements of M.stenopetala in the surveyed area were homegarden, scattered intercropping, hedgerow, boundary planting and as live fence were the another major preference of planting.

Among interviewed respondents in all wealth categories (66.7\%) M.stenopetala planted in homegarden arrangements (Figure 2). According to FGD, crop tree preference in homegarden most important stress was food for household consumption and fodder purpose. Similarly it was reported that farmers distribute planting M.stenopetala tree in homegarden mainly to provide for households consumption [18]. And respondents recommended this preference for woman for the reason that women preferred M.stenopetala as it is easily gather leaves from without any effort in the homegarden mainly for household consumption. They perceived "distribution of M.stenopetala tree in homegarden is used as umbrella for under growth Homegarden root crops" during dry season, mentioned five species such as "Enset" (Ensete ventricosum), "Sweet potato" (Ipomoea batatas), "Godere" (Colocasia esculenta), "Cassava" (Manihot esculenta) and "Boyee" (Disocoria alata) production. For that reason, farmers highly distribute M.stenopetala in homegarden site.

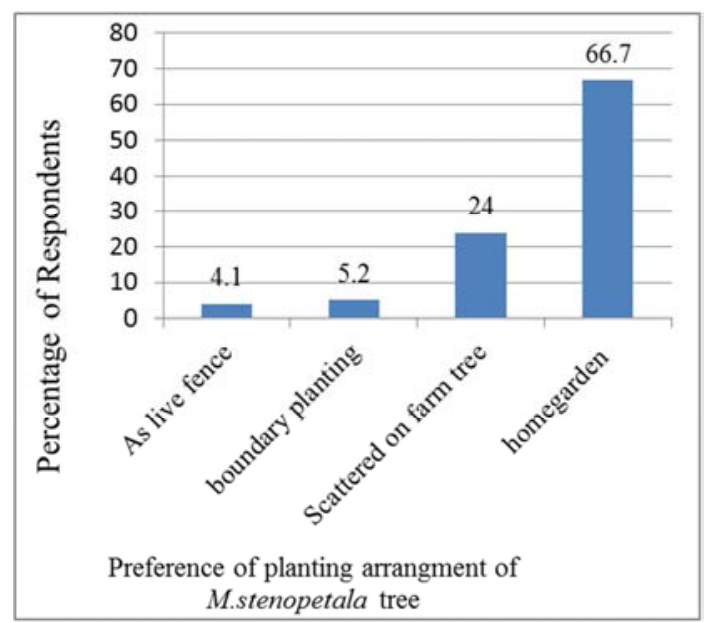

Figure 2. Planting arrangements of M.stenopetala.

Secondly, major planting practice of M.stenopetala tree 
from respondents $(24 \%)$ preferred it as scattered tree on the farm land (see below figure 3 ).
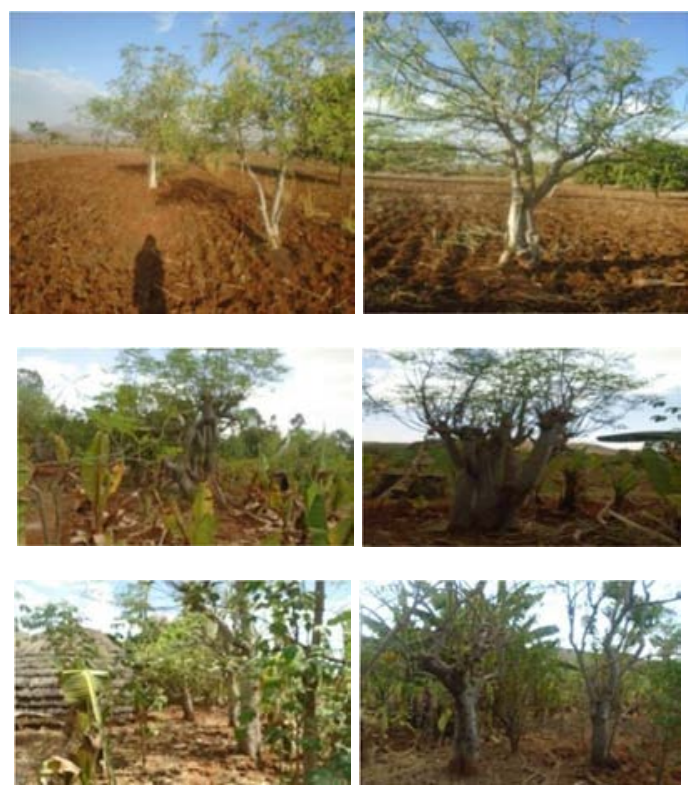

Figure 3. M.stenopetala planting practice at homegarden and scattered intercropping in site.

Therefore, some farmers recommend this planting practice in comparison it has high for seed quality and leaf yield. Also reported that marginal dry parts of Ethiopia, M.stenopetala tree is found scattered intercropped with agricultural crops by the Konso people and as on farm tree that gives more leaves and supports nearly high population density in South Ethiopia [7].

\subsection{Economic Evaluation of M.stenopetala Tree Production}

\subsubsection{Cost of Producing M.stenopetala Seedlings}

According to households' survey, they agreed in good management M.stenopetala could start providing leaves for first harvesting after planting 8-10 month but they didn't recommend this because it distorts tree growth in the future. By the help of field observations and FGD, on the average single young tree aged 2 to 4 years produce 15-25 Yiichcha ${ }^{1}$ annually and at each use/harvest they harvest 3 to 4 Yiichcha. M.stenopetala aged above 15 and repeatedly pruned

The local sales price of M.stenopetala used was the average farm gate price of sales from year 2015- 2019. Hence average farm gate price of ETB 4.00/Yiichcha was used (US \$ 0.14/Yiichcha). Marketing activities is done every day in the local area. The local traders also usually visit individual farmers in the study area to buy the leaves at the farm gate ${ }^{2}$.

In summary, the economic analysis in this study was made based on the following premises

\footnotetext{
${ }^{1}$ Yiichcha is a local unit measurement of Moringa leaves (handful or a bundle ) which one Yiichcha $=1.5$ to $2 \mathrm{~kg}$.

${ }^{2}$ Farm gate price refers to the price of Moringa leaves in the local market at study site.
}

i) A total of ten years harvests (Moringa leaf) is made each year four times harvested and maintained for the 10 year period;

ii) Harvest is started at age two;

iii) The harvested part of the M.stenopetala tree for sale was exclusively the leafy part while seed and other were left out;

Based on this assumption, results of the CBA of Moringa leaf yield was summarized below.

Table 2. Results of NPV and BCR M.stenopetala leaf yield/100tree.

\begin{tabular}{ll}
\hline Financial indicator & M.stenopetala leaf production \\
\hline NPV & 181678.22 ETB ( US 6055.94) \\
BCR & 29.98 \\
\hline
\end{tabular}

The result indicated in Table 2 above, the NPV and BCR were ETB 181678.22 ETB (US 6055.94) and 29.98 respectively with a discount rate of $6 \%$. The result showed that the discounted benefit to costs in $\mathrm{BCR}$ was higher than one. The NPV and BCR were financially sound for M.stenopetala plantation development even if on a 10 year rotation in the farm land with low cost.

\subsubsection{Benefits of M.stenopetala Tree to Local Households}

Cash income gained from M.stenopetala

According to the result of the household survey, $60.5 \%$ of households used M.stenopetala leaves as income source and whereas $39.5 \%$ of them harvest Moringa leaves for household consumption only.

Table 3. Response among wealth categories for getting cash income generation from Moringa.

\begin{tabular}{lllll}
\hline \multirow{2}{*}{ wealth status of the respondents } & \multicolumn{5}{l}{ Sold product from Moringa } \\
\cline { 2 - 5 } & Yes & No & $\boldsymbol{\chi}^{\mathbf{2}}$ & P Value \\
\hline Poor $(\mathrm{n}=17)$ & 17 & 0 & & \\
Medium $(\mathrm{n}=57)$ & 38 & 19 & 28.884 & $0.000^{* *}$ \\
Rich $(\mathrm{n}=22)$ & 3 & 19 & & \\
Total & 58 & 38 & & \\
\hline
\end{tabular}

Note $* *=$ Significant different at $\mathrm{p}<0.05$

According to One-way ANOVA the findings revealed that, the annual net income gained from M.stenopetala was highest for poor households (averaged 6787 ETB), followed by medium (4323 ETB) and rich (2145 ETB Birr) (Table 4, p<0.05).

Table 4. Average Annual cash income gained from M.stenopetala (ETB) among wealth categories.

\begin{tabular}{llcc}
\hline & \multicolumn{4}{l}{ Annually gained income from M.stenopetala } \\
\hline Wealthy categories & Mean \pm Sd & Fcal & P value \\
\hline Poor & $6787.59^{\mathrm{a}} \pm 3628.842$ & & \\
Medium & $4323.51^{\mathrm{b}} \pm 4063.477$ & 29.36 & $0.000^{* *}$ \\
Rich & $2145.45^{\mathrm{c}} \pm 4014.761$ & & \\
\hline
\end{tabular}

Key: Different Small letter indicates differences $(\mathrm{p}<0.05)$ among each wealth classes

However, as in the comparison the study indicated, poor households got relatively higher annual income from a few M.stenopetala tree leaf than fruit in the study area (table 5). This indicates poor households more depend on the 
M.stenopetala tree because it persist leaf through the year and conversely, fruit tree gives low income for them by reason of less diversity and also it harvested only once or twice per a year. It is also reported that, M.stenopetala tree is perceived by the communities as more valuable than fruit trees and farmers have started deliberately to plant M.stenopetala trees in their homestead [18].

Table 5. Comparison of Annual income of M.stenopetala leaf and fruit tree products (ETB) among wealth categories.

\begin{tabular}{llll}
\hline \multirow{2}{*}{ Source of Income } & Wealth Category & & \\
\cline { 2 - 4 } & Poor & Medium & Rich \\
\hline M.stenopetala & $6787.59^{\mathrm{c}} \pm 3628.824$ & $4323.51^{\mathrm{b}} \pm 4063.477$ & $2145.45^{\mathrm{c}} \pm 4014.761$ \\
Fruit tree & $5793.8^{\mathrm{a}} \pm 3516.44$ & $12034.5^{\mathrm{b}} \pm 6568.23$ & $18782.17^{\mathrm{c}} \pm 16253.04$ \\
\hline
\end{tabular}

\section{Food for Household consumption}

Regardless of wealth categories, $100 \%$ of the respondents used M.stenopetala leaves as main food product for household consumption. Locally it is mixed with the flours of maize, sorghum, wheat, and teff in making "kurkufa", "fosasie" and "ishkikrkir". Moringa wot is a sauce cooked in the same way as cabbage to be eaten with breads such as "maize kita", "sorghum kita", "wheat kita", "teff kita", injera and "kocho kita". It is also cooked with taro \& potato which are commonly used as substitute sources of carbohydrate to overcome the scarcity of powder from cereal crops. They use "Fosesie" mainly for breakfast because it is simple and fast to prepare and they used Kurkufa" and "Kita Be Haleko" for lunch and dinner. This is in line with the study of Abuye et al., leaves from the Moringa tree are a very important vegetable source which more than 5 million people depend on, especially during dry seasons [6].

Cultural medicinal values

The leaves, roots, seed and flowers are used as traditional medicine to prevent and treat different diseases. In the study areas, majority $(97.9 \%)$ of the respondents used the tree as local traditional medicine. Such as; $(70.8 \%)$ for malaria, $(63.5 \%)$ for common cold (cough) by adding butter in its soup and drinking at hot, $(28.8 \%)$ for hypertension (Demgifit) drinking its soup at every day morning, (9\%) for Hemorrhoid (Kintarot) mixed cooking with goat meat. [19, 20] suggested that leaf extracts of M.stenopetala are used to lower blood glucose and cholesterol levels. They informed that M.stenopetala is shown to increase body weight and reduce serum glucose and cholesterol levels in mice and its root to treat stomach $16 \%$, for animal disease (23\%), 13.5\% used seed powder for goiter. This result is in line with the finding of Assefa et al., people, use Moringa leaf as traditional medicine for malaria, hypertension and hemorrhoid [18]. Similarly, Hiawatha and Endeshaw reported that the leaves, roots, and seeds of M.stenopetala and M. oleifera have a long tradition of use in folk medicine [21, 22].

\section{Conclusion and Recommendations}

\subsection{Conclusion}

M.stenopetala tree leaves are cultivated for its different uses in the study areas. It can be used as an additional income sources and could improve households' income security for rural households mainly the poor. In general, findings of the study revealed that the majority of households' reason for planting M.stenopetala tree was to provide food nutrition. The study also observed that the major niche for planting M.stenopetala tree was in homegarden. This was due to farmers' impending that when planted in homegarden the regeneration of other underground root crop introduced in homegarden is better under M.stenopetala than other tree species. The result from the cost benefit analysis (with CBA aggregated over 10 years) revealed that the planting of M.stenopetala tree by rural households in the study area is a profitable business with highest NPV and B/C.

\subsection{Recommendations}

Currently farmers are interested in planting M.stenopetala tree which they say has a highest multipurpose value and provides local livelihoods than other farm tree species so, focus on; identifying the best and optimum silvicultural practices for the management of M.stenopetala trees in order to improve its economic and environmental values including spacing and arrangement of planting, interaction with other agricultural crops and effective methods of propagation. Study used the measurement of cost and benefit analysis about 10 year rotation production of leaf use alone to show the trend of future profitability of M.stenopetala, hence it needs additional focus on measuring cost-benefit analysis up to final harvesting/replacement of tree years including its seed and other complete use.

\section{References}

[1] Yisehak, K., Solomon, M., Tadelle, M., Contribution of Moringa (Moringa stenopetala, Bac.), a Highly Nutritious Vegetable Tree, for Food Security in South Ethiopia: A Review. Asian Journal of Applied Sciences4: 477-488 (2011).

[2] Yitebitu, M., Recommended Agroforestry/Multipurpose Trees for Borana Lowlands / Midlands and their Production Techniques. Sub-report No. 4, FARM Africa/SOS Sahel, Tropical Forestry, (2004).

[3] Fuglie, L. J., The Moringa tree a local solution to malnutrition. Dakar, Senegal. In Southern Ethiopia. SINET: Ethiopian J. Sci. 20 (1): 73-90 (2003).

[4] Amaglo, N., Moringa and other highly nutritious plant resources: Strategies, standard and markets for a better impact on nutrition in Africa. Accra, Ghana (2006).

[5] Ashfaq, M., Basra, S. M. A., Ashfaq, U., Moringa: A Miracle Plant of Agro-forestry. Journal of Agriculture and Social Science8: 115-122 (2012). 
[6] Abuye, C., Urga, K., "A compositional study of Moringa stenopetala leaves", East African Medical Journal, Vol. 80: 247-252, (2003).

[7] Dechasa, J. Sonder, K., Alemayehu, L., Yalemtsehay, M. and Agena, A., Leaf yield and Nutritive value of Moringa stenopetala and Moringa oleifera Accessions: its potential role in food security in constrained dry farming agroforestry systems. Addis Ababa, Ethiopia (2006).

[8] Lalas, S., Tsaknis, J., Sflomos, K., "Characterization of M.stenopetala seed oil variety "Marigart" from island Kokwa", European Journal of Lipid Science and Technology, Vol. 105, 23-31, (2003).

[9] Pasternak, D, A., Senbeto, S., Nikiema, D., Kumar, L., Fatondji, A., Wolter, Ratnadass and Ndjeunga, J., Bioreclamation of degraded African lands with women empowerment: The World Horticulture: 49 (2): 1-4 (2009).

[10] Eyassu, S., Actual and Potential Application of Moringa stenopetala, Underutilized Indigenous Vegetable of Southern Ethiopia. International Journal of Agricultural and food Research 3 (4): 8-19 (2014).

[11] Aynalem, A., Moringa stenopetala seed oil as a potential feedstock for Biodiesel production in Ethiopia. Addis Ababa University School of Graduate Studies (2008).

[12] Edwards, S., Tadesse, M., Demissew, S., Hedberg, I., Flora of Ethiopia and Eritrea, Volume 2, Part 1: Magnoliaceae to Flacourtiaceae. Addis Ababa University, Ethiopia, Uppsal, Sweden, pp: 660, (2000).

[13] Moges, Y., Recommended Agroforestry/Multipurpose Trees for Borana Lowlands / Midlands and their Production Techniques. Sub-report No.4, FARM Africa/SOS Sahel, Tropical Forestry, (2004).

[14] ECHO. ECHO Technical Note: The Moringa Tree. USA. www.echonet.org (accessed 24/04/2015), (2007)
[15] Radovich, T., Farm and Forestry Production and Marketing Profile for Moringa (M. oleifera). Specialty Crops for Pacific Island Agroforestry. Permanent Agriculture Resources, Holualoa, and Hawai'i. http://agroforestry.net/scps (accessed: Feb 12, 2013), (2011).

[16] Tibebu, T. and Zinabu, W. 2016. Climate Change Impacts on Agriculture and Adaptive Strategies of the Farming Community in Offa Woreda, Wolaita Zone SNNPR. Canadian Journal of Agriculture and Crops, 1 (2): 50-59, (2016).

[17] International Monetary Fund, The Federal Democratic Republic of Ethiopia; IV Consultations-Staff Report; Public Information Notice on Executive Board Discussion. IMF: Country Report No 12/287, (2012).

[18] Assefa, A., Emiru, B., Tewodros, T. and Kiros Meles, H., Moringa stenopetala Tree Species Improved Selected soil properties and Socio-economic Benefits in Tigray, Northern Ethiopia. World Agroforestry Centre. 4 (2): 68-78, (2015).

[19] Gebreselassie. D and Yalemtsehay. M., The effects of Moringa stenopetala on blood Parameters and histopathology of liver and kidney in mice. Ethiop. J. Health Dev, 25, 51-57, (2011).

[20] Lock, K., Pomerleau. J., Causer. L., Altmann, D. R. and Mckee, M., The Global Burden of Disease Attributable to Low Consumption of Fruits and Vegetables; Implications on Global Strategy on Diet. Bulletin of World Health Organization. Feb. 2005, 82: (2) (2005).

[21] Hiawatha, B. H., All Things Moringa. The Story of an Amazing Tree of Life. www.allthingsmoringa.com (accessed: January 09, 2013), (2010).

[22] Endeshaw, H. G., Promoting the Miracle Tree of Hope. Ethiopian Herald. Addis Ababa University, Ethiopia, (2003). 